\title{
Living under threat: psychosocial effects on victims of terrorism
}

\author{
Javier Martín-Peña ${ }^{a}$, Ana Andrés ${ }^{b}$, Pedro J. Ramos-Villagrasa ${ }^{a}$ and Jordi Escartín ${ }^{c}$ \\ aepartment of Psychology and Sociology, University of Zaragoza, Zaragoza, Spain; ${ }^{\mathrm{b}}$ National Institute of \\ Physical Education (INEFC), University of Barcelona, Barcelona, Spain; 'Department of Social Psychology and \\ Quantitative Psychology, University of Barcelona, Barcelona, Spain
}

\section{ABSTRACT}

The fact of being under terrorist threats, such as death threats or intimidations, has psychosocial effects and impacts on victim's psychosocial functioning. However, little attention has been paid to the study of threatened people through an evidence-based research. This study analyses quantitatively the experience of threatened people within a context of terrorism. Specifically, we want to gain insight into victims' perceptions of their threatening situation, through participants who were under threat by the Euskadi ta Askatasuna (ETA) (Basque Homeland and Freedom) terrorist group in the Basque Country, Spain. Through a crosssectional study and Principal component analysis, 87 victims of the ETA terrorist group in the Basque Country were surveyed, during the period of violence. The findings suggested six main psychosocial effects on threatened individuals, comprising issues such as (1) Thought processes and risk perception; (2) Emotional reactions; (3) Circles of vulnerability; (4) Suspicion/distrust; (5) Social interactions and (6) Safety and freedom of movement. In addition, victim's perception of control was negatively related to the psychosocial effects, in factors 1, 2, 3 and 5, respectively. The article discusses and shows implications of the power of threats, along with their effects, as a psychosocial coercion instrument.
ARTICLE HISTORY

Received 30 January 2016

Accepted 2 June 2016

KEYWORDS

Terrorism; terrorist threats; psychosocial effects; psychosocial functioning; victims; ETA

\section{Introduction}

Terrorism lies not only in blatant violence and its immediate effects, but also in the future threat of violence, creating a climate of fear and fear of repetition (Schmid, 2011). Therefore, when one is under threat by an individual or by a group through behaviours such as death threats, intimidations, extortion, among others, the threatening situation tends to include the lifetime of the individuals in the sense that impact the present, the past and the future. Living under threat can impact on the present of the individual (e.g. the impact that produces a death threat in daily life), the past (e.g. when that death threat had a consequence such as an attack) and the future (e.g. the potential risk that the death threat will become a true attack). Therefore, being threatened is a relevant issue in terrorist violence, which goes beyond an intra-individual level. The case of the Danish cartoonist who has been living in fear since he drew a Muhammad cartoon, or the case 
of threats and killings against Charlie Hebdo magazine in Paris (BBC, 2015) are examples of how violence or series of violent acts are aimed to create a psychological effect (i.e. fear or terror) apart from their physical result. It often involves a high level of uncertainty in the daily life of the threatened individual.

Within the issue of threatened people, the case of the violence perpetrated by Euskadi ta Askatasuna (ETA) terrorist group in the Basque Country (Spain) has had a great social relevance. Although there is no agreement, some studies have estimated that there were around 40,000 individuals living under threat (Bilbao, Merino, \& Sáez de la Fuente, 2013; Santos, 2008; Varona, 2009). Hence, our aim is to analyse the impact on the psychosocial functioning of people threatened by a terrorist organization. To do so, we analyse the experience of people who were under threat for years by the ETA (Basque Homeland and Freedom) terrorist group in the Basque Country (Spain).

As far we know, the first specific study on threatened people in the Basque Country was developed by Varona (2009) through interviews and the focus group technique on threatened participants by ETA. With respect to effects, the study highlighted the lack of freedom, rights and well-being in family and daily life, which may foster isolation. Larizgoitia et al. (2011) in their research about direct victims of attacks in the Basque Country suggested the anxiety as a key issue related with the experience of threats. In this sense, some studies have examined the phenomenon of threatened people in the Basque Country (e.g. MartinPeña, Rodríguez-Carballeira, Escartín, Porrúa, \& Olff, 2011; Martin-Peña \& Varela-Rey, 2014). Through a content analysis of victims' testimonies, they proposed an initial classification of the possible psychosocial effects, which showed how the fact of being under threat has also relevant effects on daily life, even in the absence of terrorist attacks or physical assault. These studies have also attempted to describe victims' experiences through this classification, reporting a relationship between acts of terrorist threats and their effects.

Despite this, the fact of being under terrorist threats have had few systematic investigations (Nijdam, Gersons, \& Olff, 2010) in part because, of the research has often tended to focus more on the effects of blatant terrorist violence than on the situation of threatened people and its effects (Pereira, 2004). Most existing studies examined effects of terrorist threats through qualitative approaches (Martín-Peña, Rodríguez-Carballeira, Varela-Rey, Escartín, \& Saldaña, 2015), often conducted by need to understand the foundations (the logic) of what is going on within the studied context (Williams, 2011). Therefore, these approaches have been essential to understand better the hidden victimation that represents threatened people (Martín-Peña et al., 2015; Nijdam et al., 2010; Varona, 2009), and in addition, to address complementary new studies.

However, currently, the research seems not to have achieved to map the comprehensive structure of psychosocial effects domains on people living under terrorist threats. Therefore, this study can contribute to determine whether there is an identifiable, coherent and theoretically interpretable structure of the psychosocial effects, useful to complement previous studies and to shed light on the way the psychosocial domains are impacted on threatened individuals.

\section{Threatened people and terrorist violence: characteristics and consequences}

The effects of terrorism are not limited to the direct victims of an attack. They may have social and political consequences on the society as a whole, in the sense that terrorism 
can induce fear in people and societies, even when these societies have not had direct experience with it (Jasko, Kossowska, \& Sekerdej, 2013). Thus, the threat of violence is a relevant element as conditional harm instilling fear. According to Schmid (2011), threats gain credibility from previous violent events, and many people live in fear of body injury or even death. Furthermore, the violence perpetrated is a kind of 'exemplary deed', and it is an instrument for intimidating, impressing or coercing other parties who are linked, directly or indirectly, to the victims or target group. Perpetrators harm their victims to indirectly influence to an ultimate target (i.e. government, policy decisionmakers). Consequently, terrorist groups often terrorize to a target group using it as a symbol and as an instrument in order to spread insecurity and fear to the public. The terrorist group can threat to kill the targets, to intimidate or to coerce them, turning this targets into threatened collectives (Martin-Peña, Rodríguez-Carballeira, Escartín, Porrúa, \& Winkel, 2010; Nijdam et al., 2010). In this sense, Morewitz (2008) argued how terrorist groups make death threats and other behaviours of intimidation to service them to achieve their goals.

A few studies have researched terrorist threats and their psychosocial consequences or the impact that threatening situations have on targeted people's psychosocial functioning (Nijdam et al., 2010). Ro and Clark (2009) noted that though there is little clarity regarding the boundaries of the construct of psychosocial functioning, it involves the specific daily 110 behaviours and the subjective evaluation of normally functioning as satisfaction and quality-of-life on the different domains (e.g. relationships) of the daily life. Therefore, the threat of imminent terrorism can also be very detrimental to individuals' psychological well-being (Canetti, Rapaport, Wayne, Hall, \& Hobfoll, 2013).

As regards to people under threat, one of the most extensive works on psychosocial effects on threatened people was carried out by Nijdam, Olff, de Vries, Martens, and Gersons (2008a) and Nijdam et al. (2010), who reviewed this specific topic on the victim/threatened individual, and analysed a collective under threat such as Dutch politicians. In addition, these authors analysed issues of terrorist threats, aiming to gain more knowledge about these situations in order to create future interventions that may mitigate the effects of threats.

The study of Nijdam et al. (2008a) highlights that the threat and protection measures become a source of chronic stress, with a variety of effects. With regard to mental health, post-traumatic stress symptoms have been found in some cases as emotional reactions (i.e. hyper-vigilance, startled reactions, difficulty concentrating, depressed mood, panic symptoms and physical symptoms such as tension and increased anxiety or fatigue). In addition, some people may increase alcohol consumption as a coping strategy to decrease tension elicited by threats. For instance, this have been found within the context of political violence in Northern Ireland, through increasing of alcohol and taking medication to cope with nightmares and dreams on a violent environment in which fear is spread (Monaghan, 2013; Morrissey, Smyth, \& Fay, 1999).

Precisely, when a person copes with a danger situation, the stress response is activated and it can influence on thought processes, which comprises to the ability to assess situations, receive and understand information and draw conclusions. Thus, threats may impact on thought processes of threatened people, influencing on the perception of the individuals' world (i.e. through worrying and obsessive thoughts about safety and uncertainty). The disruption of the cognitive processes may compromise the accurate 
assessment and interpretation of the environment. In addition, for a targeted individual, suspicion may trigger a dysfunctional interpretation of his/her direct context. For instance, freedom of speech may be affected in the case of threatened politicians, who may be more cautious when making specific statements in their public communications, or even resign due to the pressure, as well as the side effects in the family and other social circles. These circles refer to the close environment, often so-called 'circles of vulnerability' (Nijdam et al., 2008b; Plotkin Amrami, 2014). The first circle of this close environment would comprise the threatened person, the second would include relatives, the third would be friends and the fourth would consist of classmates, co-workers or children's schoolmates. The changes and disruption in social interactions can be related to the restrictions and reduced activity such as the limitation of freedom of movement, often produced by the protection measures and precautionary behaviours (e.g. limiting visits to public places considered as a risk). Thus, these safety measures are disruptive elements in the daily life of the targeted person. It also involves changes in basic everyday routines (e.g. from going to the gym to opening the mailbox), avoiding certain risk locations. Therefore, terrorist threats can end up impacting the individuals' psychosocial functioning, on professional practice, health, private life and safety. As the work from Nijdam et al. (2008a) is based on review of literature, they recommended conducting systematic research, for instance, through questionnaires and evaluations in larger samples. Through these studies should find out to gain better understanding of the effects and how adaption can be improved within these stressful situations, such as the individuals under terrorist threats.

With respect to improve the life of people under threat, a sense of control seems to make adaptation to this adverse situation easier. Within the situation of terrorist threats, individuals may experience different levels of stress to similar events because of their differences in cognitive appraisal of the situation, which was studied through Appraisal Theory of Stress (Lazarus \& Folkman, 1984). When control increases, it predicts improved emotional states and lower anxiety levels (Moser \& Dracup, 2000). In this sense, an increased perception of control may be useful as a buffer against the negative impact of these stressful experiences (Hay \& Diehl, 2010). On the contrary, a lack of control over aversive stimuli strengthens fear responses (Steptoe, 2007).

\section{ETA's violence in the Basque country: a case study on threatened people}

With regard to threatened people, the case of violence of ETA in the Basque Country in Spain has been relevant because of the number of people who were under threat, and the process of terrorizing in this region against the target group during several decades. ETA emerged in 1959 as an armed group, perpetrating terrorist violence as an instrument for separatist motives (to secure the independence of the Basque region including four provinces in Spain - the Basque Country and Navarra - and three territories in southwestern France). It is important to notice that since 2011 the terrorist group has ended its armed activity, although the organization has not disbanded. A recent and extensive review of the history and evolution of ETA and its network can be found in Muro (2008) or Lopez-Romo (2015).

Within the ETA's strategy, violent acts and selection of targets or victims were key components to achieve the goals through a process of terror. The terrorist group fostered a 
context of harassment through attacks, killings, threats and intimidating acts in the Basque Country and Navarra (Martin-Peña et al., 2010; Varona, 2009) producing a 'social spread of terror' (De la Calle \& Sánchez-Cuenca, 2004; Fernández Soldevilla \& Lopez-Romo, 2012). Therefore, the fact of being under threat mean that some people were targeted by the terrorist group and suffered a systematic use of harassment, through threats, intimidation, extortion, aggression, among others, including murder (Gesto por la Paz, 2000). Target selection was mainly based on the profession, membership in certain political parties, political beliefs or ideology, public position, or criticism of the terrorist organization (Varona, 2009). Threatened people included civilians, such as democratic representatives (e.g. council member), judges, prosecutors, prison officers, journalists and university professors (i.e. when they showed criticism to ETA), and businessmen/businesswomen, among others, as well as military forces and police (Varona, 2009). With regard to victims and from a victimological approach, Beristain $(2007,2009)$ argued that though statistics of victims of terrorism often highlight direct victims (e.g. people killed, injured or kidnapped) terrorism also produce many macrovictims, as indirect victims (e.g. relatives, friends of a direct victim, threatened people).

\section{Aim of the study}

To examine the psychosocial effects on threatened people, we generated the following questions: What are the psychosocial effects of terrorist threats on victims? How do terrorist threats alter the landscape of the individuals? The present study examines the psychosocial effects of terrorist threats in a sample of individuals under threat. Specifically, the study analyses the perception of the threatening situation through participants who were targeted by the ETA terrorist group in the Basque Country, Spain. The contribution of this study is aimed to researchers, practitioners and policy-makers interested in contexts characterized by terrorism-violence (even considering the particularities of each country). Through the analysis of this specific sample, lessons learned may be compared to other international contexts within the people under terrorist threats.

\section{Method}

\section{Participants and procedure}

This article is part of a larger study that investigates terrorist violence in the Basque Country through victims of the ETA terrorist network in the Basque Country. Individuals threatened $(N=87)$ by the terrorist group in the Basque Country answered a web-based survey designed to assess the study aim. First, participants were contacted through eighteen key informants, who were selected because of their experience as threatened individuals (e.g. suffered death threats, intimidation) and/or their knowledge about victims of ETA in the Basque Country. It is important to point out that the violence of ETA was active during the field study, conducted in 2009. Therefore, participants' confidentiality was maintained, and all the personal information (i.e. phone numbers) was coded in a protected database. Discretion in the meetings with key informants was used because some of them were targets. 
Second, we e-mailed a letter of invitation to participate in the web-based survey to a sample of people threatened by ETA, based on the information provided by the key informants. We used snow-ball sampling because it is recommended for contacting hidden populations in conflict situations (Cohen \& Arieli, 2011). In our study, key informants spread the letter of invitation to participate, and there is no information about who received it and responded. Though it is a limitation, also is at the same time a strength because this method is key in recruiting interviewees in conflict environments where there is lack of contact information (e.g. whom to interview) and also an atmosphere of fear and distrust. We requested the collaboration of participants to help us gather information about their experiences of the consequences of violence, guaranteeing safety and confidentiality.

The sample was made up of a total of 87 individuals with the following characteristics: $72.4 \%$ were male, ages ranged from 40 to 49 years old, and most of them were born in the Basque Country (78.2\%). The place of residence was mainly in the city $(46.0 \%)$ and villages (44.8\%) within the Basque Country, whereas $9.2 \%$ lived in other areas outside the Basque country. Mid (70.1\%) and mid-low (16.1\%) were the most common socioeconomic levels. The most frequent occupation: politics (41.1\%), private sector $(21.1 \%)$, educational $(11.1 \%)$, freelance $(6.7 \%)$, retired $(5.6 \%)$. The length of years being under threat: $M=10.3, \mathrm{SD}=6.3$. A $35.6 \%$ pointed out that suffered some kind of attack (e.g. arson, paint-bomb).

\section{Measures}

In addition to the sociodemographic data, the following variables were examined:

\section{Psychosocial effects of terrorist threats}

It was assessed by an ad hoc questionnaire, designed to find out how participants' daily lives were affected by terrorist threats in that context. The items are based on previous studies (e.g. Martin-Peña \& Varela-Rey, 2014) on terrorist threats and effects. A total of 30 items were retained from an initial pool of 43 , after performing statistical analyses. Participants were asked to indicate the intensity or degree to which they experienced each of the situations on a 5-point Likert scale ranging from 0 (nothing) to 4 (extreme). The internal consistency (a) for the 30-item scale was .95 (see Table 2).

\section{Single-item perceived control measure}

It was assessed through the following item on a 10-point scale:

Some people feel that they have total freedom of choice and control over their lives, while others feel they have no real control over what happens. Please indicate what degree of freedom of choice and control you think you have over the way you lead your life.

The end-points of the scale were anchored (i.e. $1=$ 'No control over life', to 10 'Complete control'). The option of a single item was chosen for this measure because of its simplicity and adaptability to populations and circumstances where this simplicity is required (Bowling, 2005). 


\section{Anxiety and depression}

It was assessed by The Hospital Anxiety Depression Scale (HAD; Zigmond \& Snaith, 1983), adapted to Spanish by López-Roig et al. (2000). Participants were asked to respond to this 14-item questionnaire, which evaluated the existence of anxiety and depression. Responses were rated on a Likert scale ranging from 0 (never) to 3 (always). In the present study, the observed reliability (a) was .91. An example of an item from this scale was: 'I feel tense or wound up'.

\section{Posttraumatic stress disorder}

It was assessed by the Davidson Trauma Scale (DTS; Davidson et al., 1997), adapted to Spanish by Bobes et al. (2000). This scale provides a measure of severity and frequency of Post-traumatic Stress Disorder symptoms, based on DSM-IV-TR criteria, through a17item on a Likert scale. For frequency, the scale ranges from 0 (not at all) to 4 (every day). For severity, the range is from $0 \multimap$ al all) to 4 (extremely distressing). An example of an item: 'Have you had distressing ims about the event?' We obtained the total score of DTS scale. Internal consistency (a) of the scale was .96.

\section{Experience about effects of being threatened}

The survey had an open-ended question in which participants could describe additional sources of information about their experience of effects of being under threat.

\section{Data analysis}

Principal component analysis (PCA) was conducted by examining the psychosocial effects on individuals, because while we had an organizing framework to guide our selection of the items to include, we did not have a strong a priori theory regarding the underlying structure of our data (Henson \& Roberts, 2006). And in any case, our primary purpose is not to test specific hypotheses. Factors were retained according to the scree test and the Kaiser-Guttman rule, which suggests keeping those factors with eigenvalues greater than 1.0. The pool of 43 items was organized in a questionnaire that was administered to the threatened individuals. Psychosocial effects were also studied by analysing the correlations between the categories and other related constructs. The analysis of the results was conducted with PAWS-18 software. In addition, we used some qualitative excerpts collected from participants through the open-ended item, with the only purpose of illustrating the factors derived from PCA. Spearman rho correlation was applied to test the possible association between perceived control and factors obtained in the former PCA.

\section{Results}

\section{Psychosocial effects of living under threat: PCA}

First of all, we conducted a descriptive analysis of the initial pool of 43 items. As recommended by Nunnally and Bernstein (1994), item-total corrected correlation was calculated, and the 3 items with a corrected correlation lower than .40 were eliminated. Maximum endorsement frequency was set at $80 \%$ (Streiner \& Norman, 2003). Based on these criteria, one item was deleted because a high percentage of participants answered 
the same ('always') option. The same thing was done for the item-subscale score correlation, and 7 more items were eliminated. Inter-item correlations above 0.7 with various test items were eliminated (Guarino, Lamping, Elbourne, Carpenter, \& Peduzzi, 2006). The 32 remaining items made up the version of the questionnaire. Potential factors were extracted through the Principal Components Analysis (PCA) followed by Oblimin rotation. The data were considered suitable for factor analysis following the KaiserMeyer-Olkin Measure of Sampling Adequacy $\left(\mathrm{KMO}=.865 ; X^{2}(496, n=87)=2386.905, \sqrt{p}\right.$ $<.0001)$. Hence, we examined the content of the items that defined a particular factor, and we eliminated 2 items that were conceptually slightly different from the majority of the items showing high loadings. Therefore, six factors based on 30 items provided an interpretable solution (See Table 1). The eigenvalues were above 1, accounting for $75.17 \%$ of the total variance. Analysis of the 30 items revealed six factors comprising the psychosocial effects of being under terrorist threats. The factor structures, including the items with their factor loadings, are showed in Table 1. The internal consistency $(a)$ for the Factors is showed in Table 2.

\section{Factor 1: thought processes and risk perception}

It was the most salient factor and included 7 items that explained approximately $46 \%$ of the variance in participants' responses. This factor shows the cognitive interpretation of the threatening situation, focused on the perception of vulnerability to risk and uncertainty. It can comprise anticipatory cognitions and fears: experiencing an attack against oneself and/or against one's close environment; being the next target; being publicly recognized; thoughts of dejection, and thoughts of abandoning the current situation and place of residence. A participant describes the experience related to daily life under threat: It is impossible to say what it means to live every day on 'death row', where you can say goodbye to your wife, parents or children in the morning, and it is possible that you will never see them again.

\section{Factor 2: emotional reactions}

It included 7 items and accounted for $9.59 \%$ of the variance in responses. This factor mainly shows the negative responses to the specific stressful and threatening situation, comprising a wide spectrum of responses to being under threat, such as feelings of sadness, anxiety, feeling overwhelmed, feelings of restlessness or irritability, or taking medication to cope. A participant notes her case: My father was threatened by ETA and suffered from great anxiety and stress, which obviously extended to the rest of the family.

\section{Factor 3: circles of vulnerability}

It included 4 items that explained $7.14 \%$ of the variance in responses. It refers to the impact and suffering caused by the situation of threat to people's immediate environment, such as the spouse, children or relatives. An excerpt exemplifies its focus on the intimate relationship: It is a 'lost life' because no one can imagine what it means in an engagement or marriage... The 'stolen life' that no one will ever return.

Another participant noted about the children: Your children are marked forever, and they are still small (11 and 8 years old), and they have learned to value what their mother and father do. 
Table 2. Correlations matrix between factors of psychosocial effects and other scales.

\begin{tabular}{lccccccccccc}
\hline Construct & $M$ & SD & 1 & 2 & 3 & 4 & 5 & 6 & 7 & 8 & 9 \\
\hline 1. Thought processes and risk perception & 2.12 & 1.25 & $(.91)$ & & & & & & & \\
2. Emotional reactions & 1.51 & 1.18 & $.73^{* *}$ & $(.92)$ & & & & & & \\
3. Circles of vulnerability & 1.46 & 1.11 & $.60^{* *}$ & $.40^{* *}$ & $(.79)$ & & & & & \\
4. Suspicion/distrust & 1.85 & 1.29 & $.68^{* *}$ & $.62^{* *}$ & $.53^{* *}$ & $(.90)$ & & & \\
5. Social interactions & 1.22 & 1.11 & $.72^{* *}$ & $.72^{* *}$ & $.56^{* *}$ & $.58^{* *}$ & $(.84)$ & & & \\
6. Safety and freedom of movement & 2.58 & 1.29 & $.72^{* *}$ & $.47^{* *}$ & $.55^{* *}$ & $.60^{* *}$ & $.56^{* *}$ & $(.83)$ & & \\
7. Psychosocial impact-total & 1.79 & 0.98 & $.90^{* *}$ & $.80^{* *}$ & $.73^{* *}$ & $.82^{* *}$ & $.82^{* *}$ & $.79^{* *}$ & $(.95)$ & \\
8. Anxiety and Depression & 1.05 & 0.53 & $.47^{* *}$ & $.71^{* *}$ & $.46^{* *}$ & $.54^{* *}$ & $.54^{* *}$ & .21 & $.61^{* *}$ & \\
9. Posttraumatic stress symptoms & 1.23 & 0.84 & $.39^{* *}$ & $.52^{* *}$ & $.49^{* *}$ & $.49^{* *}$ & $.58^{* *}$ & .15 & $.56^{* *}$ & $.76^{* *}$
\end{tabular}

Note: $N=87$. Cronbach's alpha for each factor in brackets.

${ }^{* *} p<.01$.

${ }^{* * *} p<.001$.

\section{Factor 5: social interactions}

Effects consisted of 5 items and accounted for 3.99\% of the variance in responses. It refers to the disruption and even loss in social relationships, such as neighbours, which is different from the close environment. For instance: My partner became elected (local councillor) in the municipality. Then, we began to perceive rejection by those who were formerly our neighbours. Certain 'friends' turned away from us; they avoided to invite our children to events of other children .... .

\section{Factor 6: safety and freedom movement}

It consisted of 4 items and accounted for $3.41 \%$ of the variance in responses. It refers to the restriction of freedom of movement and changes in lifestyle, habits, and precautionary behaviours, linked to the need for protection and security. It may include the need for close protection or a bodyguard, self-protection, changes and restrictions in routines in daily life, avoiding certain places or groups due to safety measures. A participant describes his/her daily life under safety measures and close protection:

I have to constantly change my itineraries when I have to go shopping, to the doctor, to visit my family... etc. I had to give up walking, going to the beach or the pool ... and especially renounce improvising. All my acts must be controlled, from the simple task of opening the mailbox or using the family car, or the way of being in a public place (always facing the entrance).

Another participant noted: I am more distanced from people because my freedom of movement is more limited, and few people wish to go out with someone who is escorted.

\section{Relationships among psychosocial effects}

The six factors interact with each other, showing associations. 'Safety and freedom of movement' seems to have greater relevance in all of the resulting factors, showing an association with Suspicion/distrust $(r=.60, p<.01)$. 'Thought processes and risk perception' was strongly associated with most of the Factors, mainly with Emotional reactions $(r=.73, p<.01)$, 'Social interactions' $(r=.72, p<.01)$ and 'Safety and freedom of movement' $(r=.72, p<.01)$. 'Suspicion/distrust' and 'Social interactions' showed a strong relation with 'Emotional reactions' $(r=.72, p<.01)$, and $(r=.62, p<.01)$. 'Safety and freedom of movement' showed an association with 'Suspicion/distrust' $(r=.60, p<.01)$. 


\section{Relationship between target's psychosocial effects and health}

As Table 2 shows, Factors of psychosocial effects were significantly correlated mainly with 'anxiety and depression' measures and also with post-traumatic symptom measures, indicating a positive correlation with health problems $(r=.61, p<.01$ and $r=.56, p<.01$, respectively). Anxiety and depression measures strongly correlated with 'Emotional reactions' ( $r=.71, p<.01)$, and moderately with 'Suspicion/Distrust' $(r=.54, p<.01)$ and 'Social interactions' $(r=.54, p<.01)$. 'Safety and freedom of movement' did not show any relationship with 'anxiety and depression' or post-traumatic symptoms.

\section{Relationship between target's psychosocial effects and perception of control}

Finally, significant negative effects were found between the factors of psychosocial effects and perception of control. Perception of control was inversely and moderately correlated to the Factor $1(r=-.24, p<.05)$, Factor $2(r=-.29, p<.05)$, Factor $3(r=-.30, p<.01)$, Factor $4(r=-.27, p<.05)$ and Factor $5(r=-.32, p<.01)$. This means that when victims had a high perceived control, then the psychosocial effects were lower.

\section{Discussion}

This study has analysed the psychosocial effects of being threatened within a terrorist context, when one is a target of an armed group. Results of this study complement and adds empirical support to prior studies (e.g. Martin-Peña \& Varela-Rey, 2014; MartinPeña et al., 2011; Nijdam et al., 2008a; Nijdam et al., 2008b) about psychosocial effects of terrorist threats. The six-factor solution and the moderate and strong positive correlations among the factors suggest that the domains are interrelated pieces that make up the negative impact on psychosocial functioning, which encompasses the spheres of daily life. The findings were distributed across six domains or factors: (1) Thought processes and risk perception; (2) Emotional reactions; (3) Circles of vulnerability; (4) Suspicion/distrust; (5) Social interactions and (6) Safety and freedom of movement. The contribution of our study to the existing literature is the creation of a map of the psychosocial effects that the fact of being under terrorist threat have on individuals threatened.

The Factor 'Thought processes and risk perception', which was the most explanatory and it had the strongest association with the remaining factors, seems to be a kind of key process in response to being threatened, influencing the other domains. This may be explained by the fact that these thoughts comprise the interpretation of the stressors stemming from a threatening situation, through anticipatory cognitions and emotions in response to the uncertainty represented by living under threat. Therefore, some stress and coping models place the interpretation and perception of a stressor (threats here) between that stressor and the emotional reactions (Olff, Langeland, \& Gersons, 2005). Moreover, the threatening situation fosters continuous uncertainty, which may include fears and worries about the future risk (e.g. an aggression, an attack).

In addition, the 'Thought processes and risk perception' Factor, which includes uncertainty, showed the highest correlation with Factor 2 'Emotional reactions'. This strong association may be explained in the sense that, some studies have showed that emotions such as fear evokes cognitive appraisals of uncertainty (Lerner \& Keltner, 2000, 2001). As in 
our results, Grupe and Nitschke (2013) noted that uncertainty is related to the experience of anxiety arising from unpredictable future events. Cognitive processes (such as our Factor 1 represents) may be influenced by high activation related to physiologically activated fear (Güss, Foust, \& Dörner, 2013). Within the risk of future victimization and fear, the fear seems to be related to amplify the risk estimation, it is highly dependent on mental imagery (and thus subject to vividness effects), and sometimes responses of fear are evoked by crude and subliminal cues (Loewenstein, Weber, Hsee, \& Welch, 2001; Slovic \& Peters, 2006). For instance, a crude cue may be when a targeted individual is killed or attacked by the terrorist group, and then fear is instilled in other people who belong to the same social category (previously labelled as the enemy by the terrorist group). A more subtle cue could occur through acts of intimidation. For example, an empty box placed under the car of a threatened individual who should usually take safety measures is also a cue (looking under his/her car to verify whether there is a limpet bomb). Consequently, anxiety is a common feature because it is related to anticipatory representations of possible and uncertain future events (Grupe \& Nitschke, 2013). In addition, anticipatory victimization and the prospect of future victimization cause harm to the threatened individual, but also to the close environment (Varona, 2009).

Indeed, the factors 'Circles of vulnerability' and 'Social interactions', although with different nuances, share similar social-interaction restrictions and impacts (Nijdam et al., 2008b; Varona, 2009) narrowing relational circles (e.g. friends prefer not to visit the person because they are afraid of being in danger or even of becoming the target of a threat). Within 'Social interactions', the role played by the neighbours have been noted through the indifference and blaming to the victims (Basque Youth Observatory, 2011; De la Cuesta Arzamendi, Varona, Mayordomo, \& San Juan, 2011; Larizgoitia, Izarzugaza, \& Markez, 2009). This shows the relevance of individuals' functioning as is inseparable from their surrounding context in the sense that environmental factors influence one's functional level (Ro \& Clark, 2009). In addition, it has been related to an active role for the collaboration in the violence, for instance, through passing information needed for the terrorist group to commit a murder (Pereira, 2004).

525 In this context, increasing attitudes of 'Distrust and Suspicion' may be common, which agrees with earlier observations, in which suspicion of being followed or spied on, suspecting some people, or the constant feeling of being watched are elements related to threatened people (Nijdam et al., 2008a). As an example, one of our interviewed key informant stressed that 'being threatened in the context of violence in the Basque Country was the best road to paranoia', highlighting the relevance of psychological and psychosocial issues in terrorist violence (Schmid, 2011).

The impact on 'Safety and freedom of movement' implies the practical alteration of daily life because it involves safety measures that often require restrictions of movement. The high association between 'Thought processes and risk perception' and 'Safety and freedom of movement' can be explained because of fear tends to provoke safeguarding, which involves a constantly checking the environment for relevant stimuli as a potential risk. Thus, the individual focuses his/her cognitive capacity on monitoring the potentially threatening situation (Güss et al., 2013). One of the major behavioural consequences of terrorism consist of the precautionary behaviours people try to implement as a way to 540 decrease their vulnerability, which correlates with negative emotions (Rosenboim, Benzion, \& Shahrabani, 2012). 
When the relationships between the factors and the HAD scale were examined, the results were coherent with studies that have showed that anxiety, depression and posttraumatic symptoms are frequently related to threatening situations in terrorism (e.g. Nijdam et al., 2008a). When the relationships between Emotional reactions and the HAD scale were examined, the results showed strong correlation. Our Factor 2 mainly assessed specific features of the threatening situation while HAD scale is focused as screening instrument for underlying aspects of anxiety and depression (e.g. I have lost interest in my appearance). Clinical approaches on threatened people have highlighted the prominent role of a wide spectrum of anxiety symptoms (Echeburúa, 2004; Larizgoitia et al., 2011; Pereira, 2004; Santos, 2008). With respect to the relation between DTS scale and factors, in general, factors tend to have low correlations. The highest correlation is with 'Social interactions', which may be explained because of the avoiding element that comprises post-traumatic symptoms.

With regard to perception of control and psychosocial effects on threatened individuals, it is interesting to note that in four Factors (Factors of Thought processes and risk perception, Emotional reactions, Circles of vulnerability and Social interactions) in this study, mentioned psychosocial effects decreased when individuals perceived more control over their lives. This finding seems to be consistent with other research in the sense that fear of social threats and distress (i.e. when the individual is threatened with physical assault) is greater when people believe the situation is uncontrollable (Ehlers \& Clark, 2000; Jackson \& Gouseti, 2015; Steptoe, 2007). Herzenstein, Horsky, and Posavac (2015) suggest that perceived control over becoming a victim (whether real or illusory) may act as a positive mechanism in the sense that the person can continue living regularly within a threatening context, because he/she feels has some influence over the events 565 in one's life. Anyway, though some degree of control may help people, an excess of increasing in responsibility and concern that accompanies control can also lead to an increase in anxiety (Burger, 1989). For instance, in the case of a threatened individual, information (i.e. about the risks, protective measures) can helps to gain a sense of control, always it does not suppose an overload (Nijdam et al., 2008b).

570 Taken together, these results show a map of the impact of selective terrorist violence, perpetrated through an effects-based strategy that fostered threats and harassment as a way to influence and change the behaviour of enemies. When a person is under threat, initial responses, such as fear, anxiety, distrust and suspicion, or precautionary behaviours may save his/her life and, therefore, are adaptive to that context and situation. However, when these same responses are continued, they begin to work against the threatened individual, fostering a dysfunctional or maladaptive psychosocial functioning. It may be a paradoxical response because the same responses that, on the one hand, save your life, on the other hand, end up disrupting it. Consequently, threatened people seem to live with scarcity in terms of safety and freedom as result of the imposition of the continuous threat and fear on their life. In this sense, Mullainathan and Shafir (2013) note how different kinds of scarcity tends to capture our attention, change how we think, playing a role of a mindset constraint, because we have less mind in the rest of life, disrupting the ability to pay attention or to make good decisions. This is in line to Güss et al. (2013), who noted that high activation due threat and fear influences on level of thinking, becoming it in a short term and narrow focused, that is, in a lower resolution level of thinking. Therefore, terrorists and their supporters can take advantage of all these issues. 


\section{Practical implications}

The findings have important implications on three main axes. First, intervention programmes aimed to decrease the impact of psychosocial effects on the threatened individual. The promotion of coping could make the threatening situation more controllable. For instance, a participant in our survey mentioned that an explanatory video for threatened people in the Basque Country (showed by the Basque police) was 'intimidating', in the sense that it was only useful to instil more fear, and not to cope with this situation.

Second, intervention on the memory and the de-legitimization of terrorist violence. Knowledge about the experiences and psychosocial processes of threatened people could be included in the design of memorials or museums, which can include memory, justice and human rights, remembering victims, to address the public's attention to the violence and injustice experienced, which might otherwise be invisible or ignored (Opotow, 2011).

Third, to improving the knowledge about counter-terrorism measures, because psychosocial and behavioural analysis of victims provides better knowledge about the terrorist violence operations implemented in some contexts. Ganor (2002) pointed out that dealing with terrorism should not only imply countering the physical threat, but also the psychological effects, in order to promote counter-measures.

\section{Limitations and further research}

The findings of the present research should be interpreted carefully because it is a crosssectional study using self-report data and a limited sample size. Hence, the relations found cannot be interpreted in cause-effect terms. Nevertheless, the present study provides an initial examination of the effects of being threatened within a terrorist context, through a hard-to-reach sample. The research does not aspire to obtaining a representative sample, but rather to gaining insights about a hidden topic. Future research could examine the protection variable and its role in victims' daily life.

\section{Funding}

This work was supported by Grupo Estudios Sociedad del Riesgo [grant number S45] and The Ministry of Economy and Competitiveness [grant number PSI2013-41865-P].

\section{Notes on contributors}

Javier Martín-Peña is PhD in Psychology from the University of Barcelona. Since 2012, he is Professor within Psychology and Sociology Department, in social psychology area, at Faculty of Social Sciences and Work (Universidad de Zaragoza). He was Professor at Faculty of Psychology and Faculty of Law, at University of Barcelona. He was visiting scholar at Tilburg University (The Netherlands), at John Jay College of Criminal Justice, (City University of New York) (USA) and at Universidad Autonoma de Yucatan (Mexico). He is researcher in the group 'Invictus Research' (University of Barcelona) and the Study Group on 'Risk Society' (Universidad de Zaragoza). jmape@unizar.es.

Ana Andrés is PhD in Methodology for the Behavioural Sciencies and has a Bachelor in Psychology at the Universitat de Barcelona. Her academic experience has been mainly focused on the development, adaptation, and validation of measurement instruments within Psychology area. She has broad experience in teaching methodology at Universitat de Barcelona, and Universitat Ramon Llull. Her research experience is also related to methodology, applied to Health Sciences. In this 
regard, she has been Affiliate Academic at the University College London. She is currently working as support research specialist at the National Institute of Physical Education (INEFC) at Barcelona. anaandresv@gmail.com.

Pedro J. Ramos-Villagrasa is PhD in Organizational and Work Psychology from the University of Barcelona. Since 2014, he is Professor of the Psychology and Sociology Department at Faculty of Social Sciences and Work (Universidad de Zaragoza). Previously, he was Professor at Bureau Veritas Business School and Universidad de Oviedo. He was visiting scholar at ISCTE-IUL (Lisbon, Portugal). $\mathrm{He}$ is researcher in the Study Group on 'Risk Society' (Universidad de Zaragoza). pjramos@unizar.es.

Jordi Escartín (BSc, MA, PhD) is Associate Professor in Social and Organizational Behavior at the Faculty of Psychology in the Universitat de Barcelona. With more than 50 publications, he has made several professional and research stays in different countries within South and North America, Australia and Europe. He is Associate Researcher to the Center for Leadership and Behavior in Organizations (CLBO, Frankfurt am Main, Germany), and the Institute for Brain, Cognition and Behavior (IR3C, Barcelona). As a systemic coach and organizational consultant, he actively advices companies in Spain and Latin America.jordiescartin@ub.edu.

\section{Disclosure statement}

No potential conflict of interest was reported by the authors.

\section{References}

Basque Youth Observatory. (2011). Retratos de Yuventud 14. Cultura democrática. Vitoria-Gasteiz: Gobierno Vasco, Gabinete de prospeción sociológica.

Beristain, A. (2009). Gregorio Ordóñez, mistagogo de dignidad preeminente (reparación, dignificación y protagonismo de las macrovíctimas). Revista Penal, 24, 23-38.

Beristain, A. (2007). Víctimas del terrorismo. Nueva justicia, sanción y ética. Valencia: Tirant lo Blanch.

Bilbao, G., Merino, F. J., \& Sáez de la Fuente, I. (2013). Gesto por la Paz. Una historia de coraje y coherencia ética. Bilbao: Bakeaz.

Bobes, J., Calcedo-Barba, A., Garcia, M., François, M., Rico-Villademoros, F., González, M., ... Bousoño, M. (2000). Evaluation of the psychometric properties of the Spanish version of 5 questionnaires for the evaluation of post-traumatic stress syndrome. Actas Españolas de Psiquiatría, 28, 207-218.

Bowling, A. (2005). Just one question: If one question works, why ask several? Journal of Epidemiology \& Community Health, 59, 342-345. doi:10.1136/jech.2004.021204

British Broadcasting Corporation. (2015, January). Danish cartoonist Kurt Westergaard: Charlie Hebdo attack will lead to self-censorship. Retrieved from http://www.bbc.co.uk/programmes/p02gh0rs

Burger, J. M. (1989). Negative reactions to increases in perceived personal control. Journal of Personality and Social Psychology, 56, 246-256.

Canetti, D., Rapaport, C., Wayne, C., Hall, B. J., \& Hobfoll, S. E. (2013). An exposure effect? Evidence from a rigorous study on the psychopolitical outcomes of terrorism. In S. J. Sinclair \& D. Antonius (Eds.), The political psychology of terrorism fear (pp. 193-212). New York, NY: Oxford University Press.

Cohen, N., \& Arieli, T. (2011). Field research in conflict environments: Methodological challenges and snowball sampling. Journal of Peace Research, 48, 423-435. doi:10.1177/0022343311405698

Davidson, J., Book, S., Colket, J., Tupler, L., Roth, S., Hertzberg, M., ... Feldman, M. (1997). Assessment of a new self-rating scale for post-traumatic stress disorder. Psychological Medicine, 27, 143-152.

De la Calle, L., \& Sánchez-Cuenca, I. (2004). La selección de víctimas en ETA. Revista Española de Ciencia Política, 10, 53-79.

De la Cuesta Arzamendi, J. L., Varona, G., Mayordomo, V., \& San Juan, C. (2011). Proyecto retorno. Donostia-San Sebastián: Instituto Vasco de Criminología/Kriminologiaren Euskal Institutoa.

Echeburúa, E. (2004). Superar un trauma. Tratamiento de las víctimas de sucesos violentos. Madrid: Pirámide. 
Ehlers, A., \& Clark, D. (2000). A cognitive model of posttraumatic stress disorder. Behaviour Research and Therapy, 38, 319-345. doi:10.1016/S0005-7967(99)00123-0

Fernández Soldevilla, G., \& Lopez-Romo, R. (2012). Sangre, votos, manifestaciones: ETA y el nacionalismo vasco radical, 1958-2011. Madrid: Tecnos.

Ganor, B. (2002). Terror as a strategy of psychological warfare. Retrieved from http://archive.is/BmczK Gesto por la Paz. (2000). Ante la violencia de persecución. Retrieved from http://www.gesto.org/ violenciapersecucion.htm

Grupe, D. W., \& Nitschke, J. B. (2013). Uncertainty and anticipation in anxiety: An integrated neurobiological and psychological perspective. Nature, 14, 468-501. doi:10.1038/nrn3524

Guarino, P., Lamping, D. L., Elbourne, D., Carpenter, J., \& Peduzzi, P. (2006). A brief measure of perceived understanding of informed consent in a clinical trial was validated. Journal of Clinical Epidemiology, 59, 608-614.

Güss, C. D., Foust, A., \& Dörner, D. (2013). Fear of suicide terrorism: Consequences for individuals and politics. In S. J. Sinclair \& D. Antonius (Eds.), The political psychology of terrorism fear (pp. 107-124). New York, NY: Oxford University Press.

Hay, E. L., \& Diehl, M. (2010). Reactivity to daily stressors in adulthood: The importance of stressor type in characterizing risk factors. Psychology and Aging, 25, 118-131. doi:10.1037/a0018747

Henson, R. K., \& Roberts, J. K. (2006). Use of exploratory factor analysis in published research: Common errors and some comment on improved practice. Educational and Psychological Measurement, 66, 393-416. doi:10.1177/0013164405282485

Herzenstein, M., Horsky, S., \& Posavac, S. S. (2015). Living with terrorism or withdrawing in terror: Perceived control and consumer avoidance. Journal of Consumer Behaviour, 14, 228-236. doi:10. 1002/cb.1511

Jackson, J., \& Gouseti, I. (2015). Threatened by violence: Affective and cognitive reactions to violent victimization. Journal of Interpersonal Violence, 1-30. doi:10.1177/0886260515584336

Jasko, K., Kossowska, M., \& Sekerdej, M. (2013). Psychological determinants of the threat of terrorism and preferred approaches to counterterrorism: The case of Poland. In S. J. Sinclair \& D. Antonius (Eds.), The political psychology of terrorism fear (pp. 171-192). New York, NY: Oxford University Press.

Larizgoitia, I., Izarzugaza, I., Iraurgi, I., Ballesteros, J., Forero, C. G., Markez, I., \& y Alonso, J. (2011). Impacto de la violencia colectiva en la salud. Resultados del estudio ISAVIC en el País Vasco. Gaceta Sanitaria, 25, 108-114.

Larizgoitia, I., Izarzugaza, I., \& Markez, I. (2009). La noche de las víctimas. Vitoria: Fundación Fernando Buesa Blanco Fundazioa.

Lazarus, R. S. \& Folkman, S. (1984). Stress, appraisal, and coping. New York, NY: Springer.

Lerner, J. S., \& Keltner, D. (2000). Beyond valence: Toward a model of emotion-specific influences on judgment and choice. Cognition and Emotion, 14, 473-493.

Lerner, J. S., \& Keltner, D. (2001). Fear, anger, and risk. Journal of Personality and Social Psychology, 81 , $146-159$.

Loewenstein, G. F., Weber, E. U., Hsee, C. K., \& Welch, N. (2001). Risk as feelings. Psychological Bulletin, 127, 267-286. doi:10.1037/0033-2909.127.2.267

López-Roig, S., Terol, M. C., Pastor, M. A., Neipp, M. C., Massutí, B., Rodriguez-Marín, J., ... Sitges, E. (2000). Ansiedad y depresión. Validación de la escala HAD en pacientes oncológicos. Revista de Psicología de la Salud, 12, 127-155.

Lopez-Romo, R. (2015). Informe Foronda. Los contextos históricos del terrorismo en el País Vasco y la consideración social de sus víctimas 1968-2010. Vitoria: Instituto de Historia Social Valentín de Foronda.

Martin-Peña, J., Rodríguez-Carballeira, A., Escartín, J., Porrúa, C., \& Olff, M. (2011). Taxonomy of the psychosocial consequences caused by the violence of persecution of ETA's network. The Spanish Journal of Psychology, 14, 172-182. doi:10.5209/rev_SJOP.2011.v14.n1.15

Martin-Peña, J., Rodríguez-Carballeira, A., Escartín, J., Porrúa, C., \& Winkel, F. W. (2010). Strategies of psychological terrorism perpetrated by ETA's network: Delimitation and classification. Psicothema, 22(1), 112-117.

Martín-Peña, J., Rodríguez-Carballeira, A., Varela-Rey, A., Escartín, J., \& Saldaña, O. (2015). Victims of ETA in the Basque Country: Their experience of terrorist threats. In O. Lynch \& J. Argomaniz 
(Eds.), International Perspectives on Terrorist Victimisation: An interdisciplinary approach (pp. 49-75). Houndmills: Palgrave-Macmillan.

Martin-Peña, J., \& Varela-Rey, A. (2014). Terrorist threats in the Basque Country: Its impact on the psychosocial sphere of victims. Oñati Socio-Legal Series, 4, 507-524.

Monaghan, R. (2013). The legacy of fear in Northern Ireland. In S. J. Sinclair \& D. Antonius (Eds.), The political psychology of terrorism fear (pp. 139-155). New York, NY: Oxford University Press.

Morewitz, S. J. (2008). Death threats and violence. New York, NY: Springer.

Morrissey, M., Smyth, M., \& Fay, M. T. (1999). The cost of the troubles study. Retrieved from http:// conflictresearch.org.uk/reports/legacy-of-the-conflict/COST-OF-THE-TROUBLES-STUDY.pdf

Moser, D. K., \& Dracup, K. (2000). Impact of cardiopulmonary resuscitation training on perceived control in spouses of recovering cardiac patients. Research in Nursing \& Health, 23, 270-278.

Mullainathan, S., \& Shafir, E. (2013). Scarcity. Why having too little means so much. New York, NY; Henri Colt.

Muro, D. (2008). Ethnicity and violence: The case of radical Basque nationalism. London: Routledge/ Cañada Blanch.

Nijdam, M. J., Gersons, B. P. R., \& Olff, M. (2010). Dutch politicians' coping with terrorist threat. The British Journal of Psychiatry, 197, 328-329. doi:10.1192/bjp.bp.109.076901

Nijdam, M. J., Olff, M., de Vries, M., Martens, W. J., \& Gersons, B. P. R. (2008a). Psychosocial effects of threat and protection. Amsterdam: National Coordinator for Counterterrorism.

Nijdam, M. J., Olff, M., de Vries, M., Martens, W. J., van Duijl, E. M., \& Gersons, B. P. R. (2008b). Addendum to the report 'Psychosocial effects of threat and protection'. Amsterdam: National Coordinator for Counterterrorism.

Nunnally, J. C., \& Bernstein, I. H. (1994). Psychometric theory. New York, NY: McGraw-Hill.

Olff, M., Langeland, W., \& Gersons, B. P. R. (2005). The psychobiology of PTSD: Coping with trauma. Neuroscience \& Biobehavioral Reviews, 29, 457-467.

Opotow, S. (2011). How this was possible: Interpreting the Holocaust. Journal of Social Issues, 67, $205-$ 224. doi:10.1111/j.1540-4560.2010.01694.x

Pereira, R. (2004). Violencia de persecución en el País Vasco. Perspectivas Sistémicas, 81. Retrieved from http://www.redsistemica.com.ar/pereira.htm

Plotkin Amrami, G. (2014). Genealogy of 'national trauma', looping effect and different circles of recognition of new professional category. Retrieved from http://ethics.tau.ac.il/en/wp-content/ uploads/2014/01/national-trauma-gp.docx

Ro, E., \& Clark, L. A. (2009). Psychosocial functioning in the context of diagnosis: Assessment and theoretical issues. Psychological Assessment, 21, 313-324.

Rosenboim, M., Benzion, U., \& Shahrabani, S. (2012). Emotions, risk perceptions, and precautionary behavior under the threat of terror attacks: A field study among Israeli college students. Journal of Behavioral Decision Making, 25, 248-256. doi:10.1002/bdm.728

Santos, D. (2008). Acosados. Retrieved from http://estaticos.elmundo.es/documentos/2008/12/21/ acosados.pdf

Schmid, A. P. (2011). The definition of terrorism. In A. P. Schmid, (Ed.), The Routledge handbook of terrorism research (pp. 39-98). Oxon: Routledge.

Slovic, P., \& Peters, E. (2006). Risk perception and affect. Current Directions in Psychological Science, 15, 322-325. doi:10.1111/j.1467-8721.2006.00461.x

Steptoe, A. (2007). Control and stress. In G. Fink (Ed.), Encyclopedia of stress (pp. 568-573). Melbourne: Academic Press.

Streiner, D. L., \& Norman, G. R. (2003). Health measurement scales. A practical guide to their development and use. Oxford: Oxford University Press.

Varona, G. (2009). Atención institucional a las víctimas del terrorismo en Euskadi. Retrieved from http:// www.ararteko.net/RecursosWeb/DOCUMENTOS/1/5_1684_3.pdf

Williams, L. M. (2011). Qualitative research methods. Retrieved from http://www.svri.org/forum2011/ QualitativeResearch.pdf

Zigmond, A., \& Snaith, R. (1983). The hospital anxiety and depression scale. Acta Psychiatrica Scandinavica, 67, 361-370. 